\title{
Kelimpahan Dan Keanekaragaman Jenis Burung Di Hutan Mangrove Kampung Yenanas Kabupaten Raja Ampat
}

\author{
Petronela Lekipiou* dan Lona Helti Nanlohy*
}

Fakultas Pertanian Universitas Muhammadiyah Sorong

\begin{abstract}
ABSTRAK
Burung memiliki kemampuan hidup, kemampuan untuk berpindah dan kemampuan beradaptasi terhadap berbagai tipe tempat hidup yang luas. Lingkungan yang dianggap sesuai sebagai tempat hidup bagi burung akan menyediakan pakan, tempat berlindung maupun tempat berbiak. Setiap spesies burung memiliki tempat hidup yang berbedabeda, tempat hidup yang disukai oleh satu jenis burung belum tentu sesuai untuk jenis burung yang lain. Salah satu tempat hidup burung adalah hutan mangrove.

Metode yang digunakan dalam penelitian ini yaitu metode Concentration Counts Metode Concentration counts efektif digunakan untuk mengetahui populasi satwaliar yang mempunyai pola hidup terkonsetrasi pada suatu tempat. Peneliti berada pada suatu tempat tertentu yang telah ditentukan. Titik pengamatan ditentukan berdasarkan kondisi tempat hidup burung yang akan diamati. Kemudian mencatat dan melakukan indentifikasi jenis dan jumlah individu setiap jenis yang dijumpai dan dilihat secara langsung. Waktu pengamatan burung dilakukan pada pukul 06.00 WIT sampai pukul 10.00 WIT, dan pada pukul 16.00 WIT sampai pukul 18.00 WIT.

Terdapat 9 jenis burung yaitu jenis Kuntul karang (Egreta sacra), Tepekong kumis (Hemiprocne mystacea), Gajahan penggala (Numenius phocopus), Umukia raja (Tadorna radjah), Jagal Hitam (Cracticus quoyi), Kuntul perak (Ardea intermedia), Bambangan hitam (Ixobrychus flavicollis), Gagak orru (Corvus orru), Srigunting lencana (Dicrurus bracteatus) yang termasuk dalam 7 famili yaitu Ardeidae, Hemiprocnidae, Scolopacidae, Recurvirostridae, Cracticidae, Corvidae dan Dicruridae Nilai kelimpahan jenis burung termasuk kategori dominan $(>8)$ dan melimpah $(2,1-$ 8). Nilai kelimpahan tertinggi adalah jenis Srigunting lencana $(18,08)$ dan nilai kelimpahan terrendah adalah jenis Gajahan penggala dan Bambangan hitam (7,23). Nilai Indeks Keanekaragaman jenis burung adalah 2,17 yang termasuk dalam kategori sedang. Hal ini menunjukan bahwa apabila nilai keanekaragamannya sedang berarti bahwa lokasi tersebut mempunyai populasi burung yang sedang pula.
\end{abstract}

Kata Kunci : Kelimpahan, Keanekaragaman jenis, hutan mangrove

\section{PENDAHULUAN}

Burung adalah jenis satwa yang hidup di alam dan mempunyai peranan penting dalam menjaga kelestarian lingkungan, Burung memiliki kemampuan hidup di hampir semua tipe tempat hidup dan mempunyai kemampuan untuk berpindah dan kemampuan beradaptasi terhadap berbagai tipe tempat hidup yang luas.
Lingkungan yang dianggap sesuai sebagai tempat hidp bagi burung akan menyediakan pakan, tempat berlindung maupun tempat berbiak. Setiap jenis burung mempunyai kemampuan untuk menyesuaikan diri terhadap lingkungannya, penyesuaian yang dilakukan dapat berupa perubahan perilaku maupun pergerakan untuk menghindar. 
Burung memiliki persebaran
merata secara vertikal maupun horizontal. Persebaran dan keanekaragaman burung pada setiap wilayah berbeda, hal tersebut dipengaruhi oleh luasan tempat hidup, struktur vegetasi, serta tingkat kualitas tempat hidup di masing-masing wilayah. Burung adalah bagian dari keanekaragaman hayati yang harus dijaga kelestariaannya dari kepunahan maupun penurunan keanekaragaman jenisnya. kelimpahan dan Keanekaragaman jenis burung yang hidup pada suatu tempat dapat mengindikasikan kondisi lingkungan di tempat tersebut. Sebagai salah satu komponen dalam ekosistem, keberadaan burung dapat menjadi indikator apakah lingkungan tersebut mendukung kehidupan suatu organisme lain atau tidak karena mempunyai hubungan timbal balik dan saling tergantung dengan lingkungannya. Burung sebagai indikator perubahan lingkungan, dapat digunakan sebagai indikator dalam mengambil keputusan tentang rencana strategis dalam konservasi lingkungan yang lebih luas.

Burung merupakan satwa yang memiliki arti penting bagi suatu ekosistem maupun bagi kehidupan manusia. Atas dasar peran dan manfaat ini maka keberadaan burung perlu dipertahankan.Burung memiliki banyak manfaat dan fungsi bagi manusia, baik secara langsung maupun tidak langsung. Manfaat dan fungsi burung secara garis besar dapat digolongkan dalam nilai budaya, estetik, ekologis, ilmu pengetahuan dan ekonomis. Alikodra (2002) menyatakan bahwa burung memiliki peranan penting dari segi penelitian, pendidikan, dan untuk kepentingan rekreasi dan pariwisata.

Manfaat dan fungsi burung yang begitu besar bagi kehidupan manusia, sehingga mendorong upaya untuk menjaga kelestarian dan keanekaragamannya. Kegiatan manusia dalam hal merusak tempat hidup burung yaitu dengan melakukan perubahan fungsi lahan untuk pemukiman, peternakan, perkebunan, perindustrian, pertambangan dan lainnya. Kegiatankegiatan tersebut membutuhkan lahan yang cukup luas, sehingga tempat hidup burung semakin berkurang dengan bertambahnya kegiatan yang dilakukan manusia untuk memenuhi kebutuhan hidupnya. Kegiatan-kegiatan tersebut dapat menyebabkan kepunahan yang melampaui tingkat pengembaliannya..

Hutan mangrove adalah daerah peralihan antara daerah daratan dan lautan. Daerah ini umumnya ditumbuhi oleh jenis vegetasi yang khas berupa tumbuhan yang relatif toleran terhadap perubahan salinitas, karena pengaruh pasang surut air laut. Hutan mangrove berfungsi sebagai pelindung pantai yang dapat mengurangi dan mencegah terjadinya pengikisan daerah pantai. Hutan ini juga berperan dalam mendukung kehidupan fauna didaerah pesisir dan lautan. Mangrove merupakan tempat hidup bagi berbagai jenis satwa seperti primata, reptilia, dan burung. jenis burung yang hidup di daerah mangrove memiliki ciri dan kekhasan tersendiri bila dibandingkan dengan jenis yang hidup di hutan alam, karena sifat khas hutan mangrove.

Setiap jenis burung memiliki tempat hidup yang berbeda-beda, tempat hidup yang disukai oleh satu jenis burung belum tentu digemari dan sesuai untuk spesies burung yang lain. Salah satu tempat hidup burung adalah daerah mangrove. Keberadaan mangrove dalam suatu wilayah sangat penting karena memiliki potensi ekologis dan ekonomis. Mangrove berfungsi sebagai tempat hidup berbagai spesies ikan, udang dan kerang-kerang, karena menyediakan banyak sumber 
nutrien yang penting sebagai sumber pakan bagi banyak spesies khususnya jenis burung-burung pantai.

Hutan Mangrove di Kampung Yenanas Kabupaten Raja Ampat merupakan tempat hidup bagi berbagai jenis burung Berdasarkan hal tersebut, maka perlu dilakukan suatu penelitian tentang Kelimpahan dan keanekaragaman jenis burung yang terdapat di hutan mangrove Kampung Yenanas Kabupaten Raja Ampat

Tujuan penelitian ini adalah: untuk mengetahui jenis dan jumlah jenis burung, untuk menganalisis kelimpahan jenis burung dan untuk menganalisis keanekaragaman jenis burung.

Manfaat dari penelitian ini adalah diharapkan dapat dijadikan sebagai bahan informasi bagi instansi terkait, mengenai kelimpahan dan keanekaragaman jenis burung serta menjadi acuan untuk penelitian selanjutnya

\section{METODOLOGI PENELITIAN}

Penelitian ini dilaksanakan dihutan mangrove Kampung Yenanas Kabupaten Raja Ampat. Penelitian dilaksanakan pada bulan Juli 2017

Alat yang digunakan pada penelitian ini yaitu: kamera binokuler, alat pengukur waktu, alat hitung, tally sheet dan alat tulis menulis, kamera, kompas dan buku panduan pengenalan burung Photographic Guide To The Birds of Raja Ampat (Yansyah \& Windesi, 2017).

Bahan atau objek penelitian adalah jenis burung yang beraktifitas di hutan mangrove. Metode pengamatan burung yaitu metode Concentration Counts. Metode Concentration counts efektif digunakan untuk mengetahui populasi satwaliar yang mempunyai pola hidup terkonsetrasi pada suatu tempat. Peneliti berada pada suatu tempat tertentu yang telah ditentukan. Titik pengamatan ditentukan berdasarkan kondisi tempat hidup burung yang akan diamati.

Kemudian mencatat dan melakukan identifikasi jenis dan jumlah individu setiap jenis yang dijumpai secara langsung Pengamatan dilakukan pada pukul 06.00 WIT sampai pukul 10.00 WIT, dan pukul 16.00 WIT sampai pukul 18.00 WIT.

Prosedur yang digunakan pada penelitian ini adalah

1. Menyiapkan peta lokasi penelitian

2. Pengamatan jenis-jenis burung yang ditemukan melalui perjumpaan langsung di lapangan.

3. Pengumpulan data dalam penelitian ini terdiri atas data primer dan data sekunder. Data primer adalah data yang didapat pada saat melakukan penelitian dan data sekunder adalah data meliputi hasil-hasil penelitian sebelumnya, keadaan umum lokasi penelitian dan data pendukung lain yang berhubungan dengan penelitian

Variabel penelitian ini yaitu:

1. Jenis dan jumlah jenis burung

2. Kelimpahan jenis burung

3. Keanekaragaman jenis burung

Data hasil penelitian akan dianalisis yaitu :

1. Jenis dan jumlah jenis burung

Data hasil penelitian akan di tabulasi berdasarkan jenis dan jumlah burung dan ditampilkan dalam bentuk tabel dan gambar.

2. Kelimpahan jenis burung merupakan total jumlah individu burung yang ditemukan selama pengamatan. Perhitungan spesies dari jumlah burung yang ada dengan melihat nilai kelimpahan tiap-tiap spesies berdasarkan rumus (Fachrul 2006) yaitu

$$
D i=\frac{n i}{N} \times 100 \%
$$

Dimana : 
$D i=$ Kelimpahan Relatif $(\%)$

ni $=$ Jumlah individu setiap spesies

$\mathrm{N}=$ Jumlah Total Indvidu

Berdasarkan jumlah kehadiran

jenis burung yang ditemukan dilapangan dapat ditentukan kategori kelimpahan menjadi lima kelas yaitu :

Dominan : $>8$

Melimpah : 2,1-8

Sering : $1,1-2$

Sesekali $\quad: 0,1-1$

Jarang $:<0,1$

3. Keanekaragaman jenis Burung

Keanekaragaman jenis burung diukur berdasarkan indeks keanekaragaman Shannon-Wiener (Fachrul, 2006), yaitu dengan rumus sebagai berikut :

Dimana :

$$
H^{\prime}=\sum\left(\frac{n i}{N} \ln \frac{n i}{N}\right)
$$

$H^{\prime}=$ Indeks Keanekaragaman

ni $=$ Jumlah suatu jenis

$\mathrm{N}=$ Jumlah seluruh jenis

Tingkat keanekaragaman dapat dianalisis dengan beberapa kriteria (Odum, 1993), yaitu :

$\mathrm{H}^{\prime}<1,0$ : Keanekaragaman termasuk dalam kategori rendah

\author{
$1,0 \leq \mathrm{H}^{\prime} \leq 3$ : Keanekaragaman termasuk \\ dalam kategori sedang \\ $\mathrm{H}^{\prime}>3$ : Keanekaragaman termasuk \\ dalam kategori tinggi
}

HASIL DAN PEMBAHASAN

A. Jenis dan Jumlah Burung di Kawasan Hutan Mangrove

Berdasarkan hasil penelitian yang dilakukan di hutan mangrove Kampung Yenanas Kabupaten Raja Ampat dan hasil wawancara dengan masyarakat ditemukan jenis burung yang hidup dan beraktifitas di kawasan hutan mangrove berjumlah 9 (Sembilan) jenis yang terdiri dari 7 (tujuh) famili jenis burung yang hidup dan beraktifitas di kawasan hutan mangrove dapat dilihat pada tabel 1 .

Tabel 1. Spesies Burung di Hutan Mangrove Kampung Yenanas Kabupaten Raja Ampat

\begin{tabular}{lllll}
\hline No & \multicolumn{1}{c}{ Jenis } & \multicolumn{1}{c}{ Nama Ilmiah } & \multicolumn{1}{c}{ Famili } & \multicolumn{1}{c}{ Status } \\
\hline 1. & Kuntul karang & Egreta sacra & Ardeidae & Dilindungi \\
2. & Tepekong kumis & Hemiprocne & Hemiprocnidae & \\
3. & Gajahan & mystacea & Scolopacidae & Dilindung \\
4. & penggala & Numenius & Recurvirostridae & \\
5. & Umukia raja & phocopus* & Cracticidae & \\
6. & Jagal Hitam & Tadorna radjah & Ardeidae & Dilindungi \\
7. & Kuntul perak & Cracticus quoyi & Ardeidae & \\
8. & Bambangan & Ardea intermedia & Corvidae & \\
9. & hitam & Ixobrychus & Dicruridae & \\
& Gagak orru & flavicollis & & \\
& Srigunting & Corvus orru & & \\
& lencana & Dicrurus bracteatus & & \\
\hline
\end{tabular}

Sumber : Hasil penelitian 2017 
Keterangan :* Burung Migran

Tabel 1 menunjukan bahwa spesies burung yang terdapat di hutan mangrove ditemukan 8 (delapan) jenis merupakan jenis-jenis lokal (penetap) dan di temukan satu jenis burung migran yaitu jenis Gajahan penggala (Numenius phocopus). Jenis burung lokal atau burung penetap adalah jenis burung yang selalu ada dan hidup serta beraktifitas di hutan mangrove. Sedangkan jenis burung migran adalah jenis burung yang bermigrasi dari tempat lain.

Dari 9 (Sembilan) jenis burung yang ditemukan di hutan mangrove terdapat 3 (tiga) jenis yang dilindungi yaitu jenis Kuntul karang (Egreta sacra), jenis Gajahan penggala (Numenius phocopus) dan jenis Kuntul perak (Ardea intermedia)

Jumlah jenis burung yang paling sering dan mudah dijumpai di hutan mangrove yang paling banyak ditemukan adalah jenis Sriguntung lencana (Dicrurus bracteatus) sebanyak 115 ekor

Selama penelitian, jenis burung tersebut dijumpai beristirahat tidur di ujung dahan mangrove dan di dalam kawasan hutan mangrove. Sebagian besar burung yang dijumpai merupakan burung penetap. Pada saat penelitian hanya ditemukan 1 (satu) jenis burung migran dengan jumlah jenis 46 ekor. Tidak ditemukankannya jenis burung migrant pada waktu pengamatan, dikarenakan tidak tepat pada musim puncak migrasi burung migrant yaitu terjadi pada bulan Nopember sampai bulan Februari dalam setiap tahunnya. (Hasudungan, 2005).
Hutan mangrove yang merupakan lokasi penelitian berbatasan langsung dengan perkampungan penduduk dan hutan dataran rendah. Hal ini menyebabkan burung yang dijumpai selama penelitian sebagian besar merupakan kelompok burung yang tidak tergantung pada perairan. Keberadaan jenis burung ini mengindikasikan hutan mangrove dapat menyediakan tempat hidup bagi berbagai jenis burung. Kelompok burung ini biasanya ditemukan di hutan mangrove untuk memanfaatkan percabangan pohon sebagai tempat beristirahat atau mencari makan. Berdasarkan jenis pakan, burung yang ditemukan sebagian besar merupakan jenis burung karnivora (pemakan ikan, serangga, vertebrata dan invertebrata), dan jenis burung yang termasuk herbivora (pemakan nektar, daun, buah, biji).

\section{B. Kelimpahan Jenis Burung di Hutan Mangrove Kampung Yenanas Kabupaten Raja Ampat}

Kelimpahan jenis burung merupakan total jumlah individu burung yang ditemukan selama pengamatan. Indeks kelimpahan memberikan gambaran suatu komposisi jenis dalam komunitas (Fachrul, 2006). Suatu habitat yang baik dapat mendukung kestabilan sebuah komunitas dari sebuah populasi.

Berdasarkan hasil penelitian, maka kelimpahan jenis burung di hutan mangrove kampung Yenanas Kabupaten Raja Ampat dapat dilihat pada tabel 2. 
Tabel 2. Kelimpahan Jenis Burung di Hutan Mangrove Kampung Yenanas Kabupaten Raja Ampat

\begin{tabular}{clcc}
\hline No & Jenis Burung & $n i$ & $D i$ \\
\hline 1 & Kuntul karang & 67 & 10,5 \\
2 & Tepekong kumis & 49 & 7,7 \\
3 & Gajahan penggala & 46 & 7,23 \\
4 & Umukia raja & 76 & 11,95 \\
5 & Jagal Hitam & 79 & 12,42 \\
6 & Kuntul perak & 89 & 13,99 \\
7 & Bambangan hitam & 46 & 7,23 \\
8 & Gagak orru & 69 & 10,85 \\
9 & Srigunting lencana & 115 & 18,08 \\
\hline & Jumlah & 636 & 100 \\
\hline
\end{tabular}

Sumber : Data Hasil Penelitian 2017

Tabel 2 menunjukan bahwa nilai kelimpahan jenis burung di hutan mangrove kampung Yenanas Kabupaten Raja Ampat menunjukan nilai dominan terdapat 6 jenis yaitu jenis Kuntul karang,Umukia raja, Jagal Hitam, Kuntul perak, Gagak orru dan Srigunting lencana dengan nilai kelimpahan tertinggi adalah jenis Srigunting lencana $(18,08)$, sedangkan yang termasuk nilai kelimpahan melimpah terdapat 3 jenis yaitu jenis Tepekong kumis, Gajahan penggala dan Kokokan laut dengan nilai kelimpahan terkecil adalah jenis Gajahan penggala dan Bambangan hitam $(7,23)$

Secara ekologi jenis burung yang memiliki nilai kelimpahan tinggi merupakan jenis burung yang memiliki peran penting dalam ekosistem yang ditempatinya. Kondisi habitat yang memiliki vegetasi yang bervariasi merupakan tempat yang baik bagi berbagai jenis burung untuk dijadikan sebagai tempat mencari makan, tempat bermain ataupun seagai tempat untuk beristirahat. Keberadaan jenis burung disebabkan oleh perbedaan jenis tumbuhan, tingkat kenyamanan dan luas lokasi dapat mempengaruhi jenis dan jumlah burung pada suatu kawasan.

Hasil penelitian menunjukan bahwa habitat mangrove merupakan lokasi yang baik untuk tempat mencari makan, dan tempat beristrirahat bagi berbagai jenis burung, hasil penelitian menunjukan bahwa jenis-jenis yang selalu menggunakan pohon mangrove sebagai tempat untuk mencari makan dan tempat beristirahat yaitu jenis Umukia raja, Srigunting lencana, Kuntul perak, dan Tepekong kumis.

Burung-burung yang beraktifitas di hutan mangrove menyebar diseluruh kawasan hutan baik di atas pohon mangrove maupun di sekitar mangrove. Besarnya kelimpahan populasi burung didukung oleh tersedianya pakan bagi berbagai jenis burung tersebut.

\section{Keanekaragaman Jenis Burung di Hutan Mangrove Kampung Yenanas Kabupaten Raja Ampat}

Menurut Mc Naughton (1998) keanekaragaman mengarah kepada keanekaragaman spesies (jenis) yang pengukurannya melalui jumlah jenis dalam komunitas dan kelimpahan relatifnya.

Berdasarkan hasil penelitian, maka kelimpahan jenis burung di kawasan mangrove kampung Yenanas Kabupaten Raja Ampat dapat dilihat pada tabel 3 
Tabel 3. Keanekaragaman Jenis Burung di Hutan Mangrove Kampung Yenanas Kabupaten Raja Ampat

\begin{tabular}{clcc}
\hline No & \multicolumn{1}{c}{ Jenis Burung } & $n i$ & $H^{\prime}$ \\
\hline 1 & Kuntul karang & 67 & 0,24 \\
2 & Tepekong kumis & 49 & 0,20 \\
3 & Gajahan penggala & 46 & 0,19 \\
4 & Umukia raja & 76 & 0,25 \\
5 & Jagal Hitam & 79 & 0,26 \\
6 & Kuntul perak & 89 & 0,28 \\
7 & Bambangan hitam & 46 & 0,19 \\
8 & Gagak orru & 69 & 0,25 \\
9 & Srigunting lencana & 115 & 0,31 \\
\hline & Jumlah & 636 & 2,17 \\
\hline
\end{tabular}

Sumber : Data Hasil Penelitian 2017

Dari hasil perhitungan nilai indeks keanekaragaman jenis ShannonWienner $\left(\mathrm{H}^{\prime}\right)$ pada lokasi penelitian untuk menunjukan Nilai $0,1 \leq \mathrm{H}^{\prime} \leq 3$ $(2,17) \quad$ menunjukkan bahwa keanekaragaman jenis pada lokasi penelitian adalah sedang. Hal ini menunjukan bahwa apabila nilai keanekaragamannya sedang berarti bahwa lokasi tersebut mempunyai populasi burung yang sedang. Sedangkan apabila lokasi yang nilai keanekaragaman jenisnya rendah mempunyai populasi jenis burung yang rendah pula. Berkaitan dengan hal tersebut maka tinggi rendahnyanya Indeks keanekaragaman jenis berkaitan erat dengan tinggi rendahnya jumlah populasi spesies tersebut dan kondisi habitat yang baik. Dengan kondisi habitat yang baik menjadikan habitat berfungsi sebagai tempat berlindung, mencari makan dan berkembangbiak. Karena kondisi tempat hidup yang baik akan selalu dimanfaatkan oleh burung sebagai tempat hidup utamanya, karena pada habitat tersebut jenis burung mendapatkan sumber pakan dan sekaligus tempat berlindung ketika ada pemangsa (predator).

\begin{abstract}
Kehadiran atau keberadaan burung dapat diartikan bahwa keberadaan atau penyebaran burung erat kaitannya dengan ketersediaan pakan dan tempat hidup (Petterson, 1980 dalam Fachrul 2007)
\end{abstract}

\section{Kesimpulan}

ini adalah :

1. Terdapat 9 (Sembilan) jenis burung yaitu jenis Kuntul karang (Egreta sacra), Tepekong kumis (Hemiprocne mystacea), Gajahan penggala (Numenius phocopus), Umukia raja (Tadorna radjah), Jagal Hitam (Cracticus quoyi), Kuntul perak (Ardea intermedia), Bambangan hitam (Ixobrychus flavicollis), Gagak orru (Corvus orru), Srigunting lencana (Dicrurus bracteatus) yang termasuk dalam 7 famili yaitu Ardeidae, Hemiprocnidae, Scolopacidae, Recurvirostridae, Cracticidae, Corvidae dan Dicruridae, dengan 3 (tiga) jenis yang dilindungi yaitu jenis Kuntul karang (Egreta sacra), Gajahan penggala (Numenius phocopus), Kuntul perak (Ardea intermedia) dan satu jenis 
termasuk burung migran yaitu jenis Gajahan penggala (Numenius phocopus),

2. Nilai kelimpahan jenis burung termasuk kategori dominan (> 8) dan melimpah $(2,1-8)$. Nilai kelimpahan tertinggi adalah jenis Srigunting lencana $(18,08)$ dan nilai kelimpahan terrendah adalah jenis jenis Gajahan penggala dan Bambangan hitam $(7,23)$.

3. Nilai Indeks Keanekaragaman jenis burung adalah 2,17 yang termasuk dalam kategori sedang. Hal ini menunjukan bahwa apabila nilai keanekaragamannya sedang berarti bahwa lokasi tersebut mempunyai populasi burung yang sedang.

\section{DAFTAR PUSTAKA}

Alikodra, H.S. 2002. Pengelolaan Satwaliar. Yayasan Penerbit Fakultas Kehutanan IPB. Bogor.

Barley, J.A. 1994. Principle of Wildlife Management. New York. Jhon Willey and Sons. Inc

Beehler, B, Pratt, T \& Zimmerman D, 2001. Burung-Burung di Kawasan Papua. Papua, Papua Niugini dan Pulau-Pulau Satelitnya. Puslitbang Biologi LIPI. Bogor.

Bibby, C; M. Jones \& S. Marsden. 2000. Teknik Ekspedisi Lapangan: Survey Burung. SKMG Mardi Yuana. Bogor.

Fachrul M F, 2006, Metode Sampling Bioekologi. Bumi Aksara.Jakarta.

Jati, A. 1998. Kelimpahan dan Distribusi Jenis -Jenis Burung Berdasarkan Fragmentasi dan Stratifikasi Habitat Hutan Cagar Alam Langgaliru, Sumba. Tesis. Program Pascasarjana IPB. Bogor.
Krebs, C.J. 1978. Ecological Methodology. Harper dan Row, Publisher, New York.

Mackinnon, J. 2000. Panduan Lapangan Pengenalan: Burung-burung di Jawa dan Bali. Gadjah Mada University Press. Yogyakarta.

Nanlohy, L. H., \& Erny Poedjirahajoe, M. P. 2010. Kajian Potensi Makrobiotik Ekosistem Mangrove di Taman Nasional Baluran (Doctoral dissertation, Universitas Gadjah Mada).

Odum, E.P. 1993. Dasar-dasa: '“' ogi. Gadjah Mada Universi, ess. Yogyakarta.

Primack, J.B.; J. Supriatna; M. Indrawa \& P. Kramadibrata. 1998. Biologi Konservasi. Yayasan Obor Indonesia. Jakarta.

Soerianegara, I. 1996. Ekologisme Dalam Konsep Pengelolaan Sumberdaya Hutan Secara Les ${ }^{\text {... }}$ dalam Ekologi, Ekologisme Pengelolaan Sumberdaya Huta

Welty, J.C. 1982. The Life of Bird. Saunders College Publishing. Philadelphia.

Wiens, T.A. 1992. The Ecology of Bird Communities Volume I. Cambridge.

Wolf, E.C. 1991. Di Ambang Kepunahan: Melestarikan Keanekaragaman Kehidupan dalam Krisis Biologi: Hilangnya Keanekaragaman Biologi. K. Kartawinata \& A.J. Whitten (penyuting). Yayasan Obor Indonesia. Jakarta.

Yansyah. E dan Windesi. R. 2016. Photographic Guide To The Birds Of Raja Ampat West Papua Indonesia. CV. Waisai Paradise. 